Article

\title{
Redemption of 'Fallen' Hero-Athletes: Lance Armstrong, Isaiah, and Doing Good while Being Bad
}

\author{
Andrew R. Meyer (D) \\ Department of Health, Human Performance, and Recreation, Baylor University, Waco, TX 76798, USA; \\ Andrew_Meyer@Baylor.edu
}

Received: 15 July 2019; Accepted: 15 August 2019; Published: 19 August 2019

\begin{abstract}
Lance Armstrong's achievements in cycling will forever be overshadowed by his admittance of using unethical performance enhancing means to win. However, Armstrong's positive social impact of raising awareness, hundreds of millions of dollars, and support for the cancer community are undeniably noteworthy. Clearly, Armstrong's hero-savior athlete depiction in the media prior to his 'fall' was related to the social 'good' he was equally known for. This good stands in stark contrast to his demonization since. This dichotomy of Armstrong's profiling offers a unique opportunity to consider how his rise and fall reflect biblical themes of a sport celebrity. This paper explores the theme of redemption specifically presented in the book of Isaiah, as I explore Armstrong's media rendering as a fallen hero-athlete following his public acknowledgement of cheating. This manuscript provides a contextual comparison of Armstrong's story to the redemption of exiled Jews as detailed in Isaiah. Throughout the paper, I present how Armstrong has received a more profound, though less obvious or common redemption through his lifetime ban from sport. Ultimately, this article provides an analysis of a contemporary hero-athletes redemption who cycled for good, while being bad.
\end{abstract}

Keywords: Lance Armstrong; Isaiah; redemption; contemporary sport culture; exile

\section{Introduction}

In 2019, another fallen athlete, Tiger Woods, won the Master's Championship golf tournament. Weeks later, he received the Presidential Medal of Freedom, the highest distinction any citizen of the United States can be awarded. Through the glowing media coverage of his comeback, sporting victory, and his elevation as an American ideal, we see the ability of disgraced athletes to regain their status after a 'fall', returning to the top of their sport and in the eyes of fans. Woods' portrayal following his personal, off-the-course misdeeds over the past decade, was harsh. However, he kept playing his sport. After his latest PGA Master's win, he was heralded as an athlete who fell from the pinnacle, to the depths, only to emerge a changed and better person, worthy of praise, admiration, and national recognition. Overwhelmingly, Woods' sponsoring companies (Kennedy 2019), the world of golf (Pelletier 2019), and the general public had forgiven him; he was redeemed. But I argue through this paper that Woods has been redeemed in less a holistic and humanly impactful way, because he could remain in sport. He was able to restore his balance (redemption) as most athletes in contemporary sport are; he was able to be a popular celebrity athlete again. This kind of redemption in athletics is common. When this sport 'redemption' occurs, however, and given the kind of redemption found in the Old Testament, the person, the human that is the athlete, is left out of the equation and redemption is partial.

This article then is focused on another athlete's seeming 'unsuccessful' attempts to regain prominence in their sport, adoration of fans, sponsorship deals, and regain a general positive public opinion for themselves. This article's focus is on arguably the most vilified and despised athlete in contemporary sport and his inability to do what Woods and many others have been able to do-regain 
his image as a hero-athlete. Partially, this is because of the immense damage he inflicted upon himself and others within his sport over the past twenty years, and his lifetime ban from competition (Millar 2013). Lance Armstrong is now known as a cheater, liar, and fallen hero-athlete, whose collapse from global elevated status affected not only his sport, his family, and his income, but also affected those who found hope in him as a cancer survivor and his philanthropic efforts for the cancer community. Tiger Woods did bad things and hurt people around him. But millions of people held Lance Armstrong up as an idol, found hope in him, and in a very clear way 'worshiped' him. His riding and celebrity status made his cancer-related philanthropy LIVESTRONG a global success, raising hundreds of millions of dollars and awareness for cancer-related issues. In doing so, Lance Armstrong, the athlete and cancer survivor, raised something less tangible-hope-which is perhaps why so many felt harmed when he admitted to taking performance enhancing substances during his professional cycling career. As millions of people experienced this hurt, redemption was going to be difficult, if not impossible to achieve in the context of contemporary sport culture.

Armstrong's performance enhancing substance use, subsequent lies, and vilification of accusers is prolific and well documented. Our examination here is not about what he did, and the shockwaves it caused through various entities, communities, and for individuals around the world. Rather, I wish to examine the evidence of Armstrong's public story through a critical comparison of a Biblical perspective to illustrate themes of redemption in his case. This examination comes twenty years after he won his first Tour de France in 1999. There are not many who have not heard about his rise and fall.

One key issue that must be addressed at the start, is that Armstrong's transgression occurred directly related to his sport performance. The thing that made Armstrong a celebrity hero-athlete was his cycling performances and his achievements on the bike. Woods' 'immoral' actions occurred away from golf, and unrelated directly to his successful performances. Even if the stress and distractions of the negative media coverage impacted Woods' play, the improper behaviors he needed to atone for and be redeemed for were of a personal kind and not directly sport related. Armstrong's immoral behaviors related directly to that which he was famous for, namely his cycling victories. Therefore, we must be aware of the deeper connections and harm Armstrong caused due to the central connections between his performance's, his popular rendering, and his transgressions.

This paper is also not an in-depth analysis of Isaiah, but rather an attempt to bring insights of this Old Testament book to bear on a critical cultural analysis of a fallen hero-athlete in contemporary sport culture. This is not an argument for the condemnation or exoneration of Armstrong; nor is this a historiography of a book of prophets, both of which fall beyond my training and ability. The discussion presented here is part of a longer conversation I have been engaged with for the past ten years. My doctoral dissertation focused on muscular Christianity, Radical Orthodoxy, and the American cyclist who was about to come out of retirement. I first began to consider how Armstrong would be redeemed (if at all) not long after he admitted to a career built on performance enhancing substances. I followed his very public fall with great interest and concern. I had been a fan of Armstrong, had watched his Tour victories, and had believed in his mission for the cancer community (and beyond). Truth be told, I still am. Many friends and colleagues asked me questions about his case, his denials, and his eventual admittance. I was even asked during a tenure review when it was going to be time to stop writing about Armstrong because he was old news. I have been with this story for a decade now, a decade filled with Armstrong's triumphant return to the sport he helped globalize, watched the veil of denials slowly come down over a period of two years, the interview with Oprah Winfrey where he stoically admitted to the wrongdoing and pain he caused others. Since 2013, I have watched the punishments come down, reading about the wider anger and pain he inflicted, and erasure of his athletic achievements. What is left, what has always been at the center of it all, is a man, a human being, who at one time had fame, popularity, and success, once described as "Jesus Christ" on a bike (Pucin 2009). Now he is a person who has experienced the erasure of all that loftiness and known for his "colossal" fall (Busbee 2019). Armstrong's story can be broken into four stages (borrowing a cycling metaphor): cancer survival, professional achievement and global celebrity, the 'fall', and life 
since. In this simplification, the cyclist's life resembles that of the Jewish people found in the book of Isaiah: remembering the Exodus and delivery to the Promised Land, thriving and success of Israel, destruction of Jerusalem, the Temple and exile to Babylon, and eventual redemption and renewal. The 'fall' and redemption pieces of the Jewish story, is where I will focus as I relate these themes to Lance Armstrong, as a partial answer to those who keep asking me what is Armstrong up to these days? Using recent evidence, this examination concludes finding redemption is at hand for Lance Armstrong when Isaiah is used as an interpretive lens.

\section{Contextualizing the Scope}

Much could be written on each of the topics below, but in this section, I wish to narrow the scope for the reader as these concepts relate to the discussion at hand. For example, the notion of redemption could be discussed in the context of various groups related to the Armstrong case (fans, the sport, individual riders). However, as this paper is about the redemption of Armstrong as a person considering notions of redemption found in Isaiah, my review of this topic, and others, is focused toward informing this.

\subsection{Isaiah}

Isaiah is the book of the Old Testament that scholars argue redefines God for the Jews, and eventually Christians, from a God of creation, to a God of salvation (Anderson 1962). The God of creation is the Exodus story familiar to those Isaiah was writing for. Isaiah's messages are about the reasons for God's condemnations of the Jews in Jerusalem during their flourishing, their punishment through exile to Babylon, and the hope they should cling to through the pain and suffering of their exile (Brueggemann 1984). Isaiah writes to foreshadow punishment as a reminder to the exiled Jews to have faith, that the redemption of Jerusalem is possible, if not a guarantee (Dumbrell 1985). This is also what soteriological scholars have identified in Isaiah as shifting away from the "old" Exodus narrative familiar to Jews living in Babylonian exile to a "new" message of hope in a purified city for God's people. As Harner (1967) says "we receive the impression that the Exodus tradition provides the grounds for believing in Yahweh's new act of redemption" (p. 303). This new rendering of God is for a people who Isaiah wishes to unhinge from holding on to 'former things' or 'things of old,' namely believing God's first Exodus was final and eternal. He wishes them to focus on 'new things' that God is doing for them now, such as delivering them from exile, and His future commitments to them. Here, Isaiah is crafting an image of God as not only creator, but also as enduring savior so that all experiences of the Jewish people fit into God's eternal plan for them, and to not only cling to the original promises and past deliverances. The God found in Isaiah as savior and redeemer, not just creator, is a clear shift in the prophets work and offers a new critical perspective for the Jewish people.

A second aspect of redemption found in Isaiah that I wish to highlight is how painful the revealing of this new truth of God is and how necessary a component for redemption these are in Isaiah. Brueggemann (1984) states in his examination of Isaiah that "each of the Isaiah's articulates a specific practice of social transformation ... the text is more than a text, it is a presentation of a way through to a world of faith" (p. 91). First Isaiah is a social criticism, a judgement, "a precise exposé of cultural practice and cultural value which engage in systemic perversion" (p. 92). A new truth emerges from Isaiah's critique of ideology. "One cannot move from critique (judgement) to promise, as Childs and Clements seem to suggest, without the intervening reality of pain expressed. Second Isaiah presumed the grief and brings it to speech, even as it is evoked by the critique of ideology ... It is the suffering of exiles, the embrace of pain made possible by critique of ideology, that permits the announcement of newness" (p. 96). The pain and suffering are a necessary condition for the new relationship Isaiah sees the Jewish people having with God after their exile.

A third aspect of redemption in Isaiah that informs the focus of this paper is the hope we read throughout his book. Anderson (1962) examines the Exodus typology in Second Isaiah, again examining the difference between a God of creation and a God of salvation. If the Jews are God's chosen people, 
how could He allow them to suffer so greatly, through the destruction of Jerusalem, the temple, and their exile in Babylon? Isaiah's book provides his insights of God's wider plan so that hope and faith in God prevail, even if current situations conflict with previously held beliefs. Anderson (1962) states Isaiah "freed Israel's religion from the particularities of Israel's history and set forth ideas and principles whose validity is independent of the historical circumstances through which they were mediated" (p. 180). In such a rendering, any event can be examined and found to be meaningful, predetermined and part of God's larger story, a story with redemptive purpose. "According to Second Isaiah the whole course of history, from beginning to end, is set within the purpose of the eternal God, the Creator, and Sovereign" (Anderson 1962, p. 187). In doing so, Isaiah encourages his readers to remember the past, learn from it, and have hope in God's power to use any situation as evidence of His redemptive ability. "The Exodus is a guarantee that Yhwh will redeem his people, for that event demonstrates that he has the wisdom and power to accomplish what he purposes. Second Isaiah spoke to a people in exile, in despair about the meaningfulness of their history and about Yhwh's power to give them a future. The prophet's intention is to awaken their confidence by proclaiming that Yhwh is the only Lord of history, for he accomplishes what he announces. Israel's redemption will surely come ... (55: 10-11)" (p. 189). This new exodus found in Isaiah "will be a radically new event. It will surpass the old exodus not only in wonder but also in soteriological meaning, as evidenced by the theme of divine forgiveness, which runs through the whole of his prophecy, or by extension of salvation to include all nations" (p. 191). Through the despair caused by their destruction and exile, Isaiah constantly provides the alternate, assuring his readers of the hope of God's eternal presence and favor, in the darkest of times, and in the unlikeliest of events.

What is important about Isaiah's themes of redemption here, is that firstly he is redefining the path of God for the Jewish people, as one from creation to that of salvation. In this reinterpretation, he is critiquing and challenging the way the Jewish people understand God and their relationship with Him. This social critique and new understanding, according to Brueggemann (1984), is essential for the revelation of truth, and a moving away from the false truth of "positivistic claims" by those with power (pp. 93-94). Secondly, inherent to this critique is that any new understandings of the truth will be painful. While the initial challenge to the dominant version of truth will cause the suffering of individuals and groups, Isiah reveals that this will be necessary for the redemption of the Jewish people. Finally, through this painful critique of old ways, Isaiah continually offers visions of how the "new" way leads to redemption and a life filled with hope. We will see these three themes later in the paper as they relate to Lance Armstrong and his path towards redemption as a person, and not just a hero-athlete.

\subsection{A Moral Role of Sport and Hero-Athletes}

Sport and religion have historically shared common elements of human communal needs and a morality. Guttmann (2004) focuses on ritual, for instance, suggesting the sport activities in pre-modern cultures "were often-perhaps usually-embedded within or aspects of religious ritual" (p. 7). Other scholars have focused on sport and religions' participation with nature (Sansone 1988) or formation of community bonds (King 2006). Shirl Hoffman (1992) writes in his work that "sport has long been regarded as a shaper and reinforcer of values deemed critical to the maintenance of American society," (p. 6), and display ritualistic "properties," like religious rituals, that "reinforce the community's commitment to society's core values" (p. 7). Some scholars suggest that sport is a "type" of religion, for example, Novak (1992) who claims sport "is not a religion in the same way Methodism, Presbyterianism, or Catholicism is a religion," but that sports generate a form of civil religion, as these formal religions "are not the only kinds of religion" (p. 35). Mathisen (1992) argues that if sport is a civil religion, then the core of sport is a folk religion because civil religions have the tendency to come and go with passing popularity (p. 18). Using Linder's (1975, p. 401) definition, Mathisen says "folk religion is a combination of shared moral principles and behavioral customs," and these principles and customs "emphasize the common religion of a people as it emerges out of the life of 
'the folk'" (Mathisen 1992, p. 19). Members of a folk religion "affirm their beliefs and practice their rituals" making up a "collective conscience" (p. 23). Albanese (1981) suggests even a third view of sport as a "cultural" religion. Such "religious forms include sacred stories, rituals, moral codes, and communities ..." (p. xxi). I contend that in contemporary sport cultural, sport takes on and fulfills all the various roles that Novak, Mathisen, and Albanese discuss. Sport thus becomes a religious and spiritual experience, with moral and ethical values, and includes hero-role models who display the ethos of the system and perpetuate an ongoing dialogue (within its confines and for the broader culture) of what it means to be good, right, and true.

As a result of the decrease in traditional religious adherents, many find the spiritual and religious messages of sport and athletes powerful and attractive (Nelson 2009). In their understanding of the nature of postmodern theology, Radical Orthodoxy scholars, such as Milbank et al. (1999), support notions that alternate areas of culture operate in spiritually and religiously significant ways. As such, sport has become a self-sustaining entity with diverse media outlets, becoming an organic whole that disseminates moral value. Through this organic and ubiquitous contemporary role, sport has become a site of religious and spiritual meaning, where athletic hero/icons reflect the hegemonic moral and ethical values deemed important today. Understood in these terms, contemporary sport is not a type of religion, but rather a cultural activity of religious and spiritual meaning in the lives of many. As Sydnor (2003) suggests "our studies and conclusions ... we might boldly answer that the developed world's obsession/fascination with ... sport-related productions and representations is the result of individual and societal emptiness that is only fulfilled by God" (pp. 26-27).

For Oriard (1982), however, a sport hero is largely a "prowess hero" rather than an "ethical hero" (p. 30). This tracks with Allison and Goethals's (2011) conclusion that "[a]lthough heroism can be used in either conscience or competence alone, most of the examples ... combine both qualities" (p. 200). Any figure or activity that dominates our attention and lives, as sport and popular athletes do today, has the trappings of idolism. As such, the heroes and icons popular in sport are empty vessels of true meaning in our lives. Whatever the justifications, often, we do hold these individuals up as moral ideals and standards bearers, forgetting that our current cultural practices and mores put athletes on pedestals, demand they be more than human in their behaviors, and thus we are implicit when they 'fall'. Meyer's (2012) work on muscular Christian reflections of Lance Armstrong in the media highlights evidence of contemporary hero-athlete worship. But as Williams (2009) states, there is an "absurdity of athlete worship" due to "the mere fact of being well known is not enough to transform athletes into moral standard bearers" (p. 13). As is often the case in contemporary culture, media is deeply involved in encouraging the sport system to rid itself of fallen sport heroes, as well as exuberant and celebratory when they return to prominence, promoting the age-old story of beating the odds and depict them as 'worthy' icons. Little scrutiny is ever given to the culture of sport itself, its socialization toward deviant behavior, and the media's role in promoting these themes.

\subsection{Redemption}

Redemption is the righting of wrongs, errors, or sins, and coming back in line with the previous or established operation of a system (religious or otherwise). Simply defined, redemption is "the process of righting a wrong and restoring balance" (Scholes and Sassower 2014, p. 131). Crimes against society are met with penalties which, upon fulfillment, individuals are said to have been redeemed. There are of course biblical perspectives of redemption. In the Old Testament, for the Israelites, redemption came when there was "recognition of the nature and gravity of" the "mistake and acknowledgment of responsibility for their sins" (Scholes and Sassower 2014, p. 132). Thus, two key themes are necessary in the context of Jewish redemption: acknowledgment a wrong has been committed and taking personal responsibility for that $\sin$.

For professional athletes, depending on their mistake, redemption can come in many forms (ejection, suspension, fines, etc.). However, all redemptive efforts must involve an acknowledgement of wrongdoing and an "explanation of why the mistake was made" (Scholes and Sassower 2014, p. 137). 
Regardless of the sin, harm, or infraction, redemption is granted by "the one sinned against," (i.e., God or others) "though neither is obligated to do so" (p. 133). In contemporary sport culture, redemption is difficult because rarely is there a specific person an athlete can apologize to and garner redemption. For example, American football quarterback Michael Vick went to prison for engaging in an illegal dog fighting ring. After serving his time in prison and paying fines, Vick returned to his career in the National Football League (NFL). In the eyes of the NFL, and in the eyes of the state, he had been redeemed. But the throngs of fans may never have given him that same "return to balance" in their perceived relationship with him. In fact, this type of redemption would be impossible. It is clear then that redemption for contemporary athletes, especially high-profile celebrity athletes, is not feasible.

As this paper is focused on comparing the redemption described in Isaiah with the story of Lance Armstrong, I am not as concerned with clarifying who and what of Armstrong's redemption. In Isaiah, we read how after their exile, the Jews were in fact not returned to the same Jerusalem, as it had been destroyed. The redemption following their exile was not a direct restoration to balance with Jerusalem (their original place) and with God, but rather to a new place and a new relationship with God. Additionally, even though all Jewish people were rescued from exile, not all 'redeemed' entered the promise of the 'new' Jerusalem or a restored relationship and balance with God. Those who returned to the city but did not have faith in God are described in Isaiah as the "wicked," and those who returned from exile with hope and a revived faith in God were called "servants" (Roberts 1982, p. 136). Examined below are the similarities of Armstrong's walk towards redemption with that of Isaiah's description of the redemption of the Jews from Babylonian exile, and how the lifetime barring from professional sport assisted in his holistic and more meaningful redemption as a person.

\section{Comparative Analysis: Isaiah and Armstrong}

The book of Isaiah is a conglomerate and many scholars have noted the complex nature by which the book became cannon, claiming with a high degree of assuredness that the Prophet Isaiah of Jerusalem most certainly did not compose the entire book (Clements 1982, p. 127; Dumbrell 1985; Anderson 1962; Roberts 1982). This paper is not a soteriological analysis of Isaiah but rather an examination of the meaningful connections between the warnings, failings, destruction, exile, and restorative promises found in Isaiah and the 'fall' and redemption of Lance Armstrong. This section provides a comparative analysis of Isaiah, in general, to Lance Armstrong's story of 'falling' from the loftiness of sport celebrity and his case for redemption. My focus will be on presenting an overview of the sections of Isaiah I wish to relate to Armstrong and then do so with evidence of his journey.

It is helpful to understand how some scholars have broken the book of Isaiah into groupings, to help readers clarify different sections and overall themes of the book. Brueggemann (1984) reads Isaiah in three parts (as do most scholars); chp. 1-39 as "a critique of ideology," chp. 40-55 as "a public embrace of pain which leads to hope," and chp. 56-66 as a "release of social imagination" (italics in original) (p. 102). Dumbrell (1985) reads the book with "an overmastering theme ... of Yahweh's interest in and devotion to the city of Jerusalem" (p. 112). He also breaks the book into parts, with chp. 1-39 representing a picture of Jerusalem in decay, "whose sacrifices cannot any longer be accepted and whose prayers must be turned aside" (p. 112). He reads the second half of the book (chp. 40-55 and 56-66) as describing the gradual change which occurs following the exile to Babylon-punishment for the sins detailed in the first half of the book. Other authors have explored specific themes found in Isaiah, and especially chp. $40-55$, focused on turning from creation to salvation, are most apparent (Anderson 1962; Harner 1967).

\subsection{Arriving at and Thriving in a Promised Land-Moving towards the 'Fall'}

Clements (1982) identifies that the first chapters of Isaiah provide examples of a city that was flourishing, but with a population that had turned away from God. The prophet's warnings reveal Jerusalem's ignorance as his prophecy is described as falling on "deafness and blindness" (Clements 1982). Isaiah highlights how the kings of Judea believe that if they turned to regional allies, 
such as Egypt and Babylon, rather than God, they could defeat the Assyrians, an immediate threat in Isaiah's book. Isaiah highlights Jerusalem as a thriving city, and in ways that very much demonstrated prior promises God had made to the Jewish people. He had delivered them from Egypt and provided Judea as the Promised Land. He bestowed the blessings of military victory, wealth, and security from enemies. By the time most scholars believe the prophet Isaiah of Jerusalem was writing, beginning in about 737 or 736 B.C.E. (Clements 1982, p. 120), the people of Jerusalem were thriving. Isaiah, however, saw dangerous trends coming, which culminated in his prophecies. He warned the continuation of Jerusalem's prosperity is "Yahweh's guidance ... not the deft political kingship or conjunction with foreign alliances ..." (Dumbrell 1985, p. 115). The first chapters of Isaiah are "a thoroughgoing indictment of the failure of Israel to be the people of God and a rejection of Jerusalem," and provide "a threat directed to a Jerusalem society given over to pride and idolatry" (p. 113).

Upon this overview of Isaiah, already some comparisons with Lance Armstrong's story can be made. Armstrong had survived Stage 3 testicular cancer, and had been regranted his health, life, and cycling career. His story of survival can be read like that of the Jewish Exodus from Egypt, who were delivered from slavery (death) to the Promised Land (life). Once Armstrong returned to cycling, he lived a profoundly successful and celebratory life; he lived in the 'promised land' of sport success. He was victorious on the bike, and popular as an athlete, celebrity, and philanthropist. He attributed his successful survival of cancer to the medical doctors and treatments, citing science as the reason he survived. A reliance on science, medical treatments, and drugs continued throughout his cycling and philanthropy. Like the Jews of Isaiah's time, Armstrong moved away from an internal need for others, a deep sense of self, and creating meaningful relationships toward specific calculated and rational alliances that kept his hero-athlete narrative intact. This also is comparable to Isaiah as the prophet was aware of the danger of false narratives promoted by powerful people and "Isaiah does a discerning critique of the power of propaganda" (Brueggemann 1984, p. 94). Much like the Jews in Jerusalem, Armstrong made strategic alliances with others that broke the moral code of his sporting world in order to falsely maintain his elevated status as hero-athlete.

Starting with his 1999 Tour de France victory, Armstrong was plagued by suspicion and claims of illegal training substances and methods by a small few, in and out of sport media. He of course vehemently denied these, as is well documented, attacking, suing, and demonizing those who questioned the purity of his performances and achievements. His followers, supporters, teammates, coaches, and others in the media defended, promoted, and protected him from the truth of these allegations. The small number of detractors were like Isaiah in Jerusalem who called for others to awake to the reality of their actions and behaviors. Like those of Jerusalem, the warnings and proof of Armstrong's illegal performances fell on deaf ears and blind eyes. Lance Armstrong rode to the most ever Tour de France wins between 1999 and 2005 (seven consecutive) and retired from the sport he had helped globalize to focus on his philanthropic efforts with the cancer community. Comparatively, when Jerusalem was under assault from Assyria, the people of Jerusalem prayed to God to save them, which He did. They felt a sense that God was with them and they could continue in the ways Isaiah was critiquing. Armstrong also seemed to have beaten all the allegations and speculation, and could go on with life, never having been caught cheating.

As with all tragic stories, however, Armstrong did not leave the sport for good. In 2009, he decided to come out of retirement and ride in that year's Tour de France. Armstrong has identified in several interviews that if he had not come out of retirement, he would not have been caught (Levy 2012). After riding in 2009 and 2010 and retiring once again from the sport, by 2012 a resurgence of claims against him had resurfaced. Comparing once again Isaiah, after the Jews had survived the Assyrians, and with their kingdom reduced in size, the Jews continued around 100 more years until eventually the prophet's forecast came to be realized (well after his death). Babylon razed the city of Jerusalem, destroying the sacred temple, and sent the Jewish people into exile. In both examples, each resided in a 'promised land,' but were not living properly. Both engaged in improper behaviors, contrary to the expected practices of their social context, wrapped up in their self-reliance, deafness, and blindness to 
truth by silencing those who dissented against them (Brueggemann 1984, p. 94). This eventually led to their destruction and exile.

\subsection{The Suffering: Destruction and Exile}

The exile of the Jewish people is foretold as the result of their sinful actions and loss of faith in God in the first half of Isaiah (chp. 1-39), with further justification and rationale provided in the second half (Harner 1967, p. 298). God levied this punishment so that His people and their wicked and sinful ways could be forgiven (Roberts 1982, p. 136). Chp. 40-55 are focused on the return of the exiles from Babylon and the restoring of their new relationship with God through the rebuilding of a new Jerusalem and temple. What we see in these later chapters is the hope realized following the painful suffering of a people who had lost their way.

If we relate the exiled experiences of the Jewish people with Armstrong's 'fall' from hero-athlete, we can again come to appreciate how the painful suffering he experienced compares with that described in Isaiah. While it is not my contention that he immediately came to be redeemed when he lost his sponsors, fans, and ultimately his affiliation with LIVESTRONG, there is ample evidence that his punishments and exile caused him to truly suffer over an extended period, a necessary experience for redemption.

After a lengthy investigation by the United States Department of Justice in February 2012, which produced no criminal charges being filed, it looked as if Armstrong was exonerated. Yet, in June of that same year, his case was picked up by United States Anti-Doping Agency (USADA). As before, Armstrong denied the allegations and sought to fight against these new cases. However, by August of 2012, with many former teammates testifying and granted plea deals, he announced he would stop fighting the charges brought by the USADA. He was handed a lifetime ban on all competitions and the disqualification of all his competitive results from August 1, 1998 onwards (USADA 2012). By October, Armstrong could no longer hide from the truth as the USADA made public a 202-page document of evidence. On 17 October, he stepped down as LIVESTRONG chairman and Nike, 24-h Fitness, Easton-Bell (Giro helmets), Trek bicycles, Honey Stinger, Anheuser Bush, Oakley Sunglasses, and Radio Shack terminated their sponsorship contracts with him (Rishe 2012; Rotunno 2012). On 22 October, the International Cycling Union (UCI) upheld the USADA's decision to strip him of his competitive record, including his seven Tour de France wins, and on 12 November Armstrong stepped down from the board of LIVESTRONG—ending any formal relationship with the foundation he created fifteen years earlier. Finally, on 17 January 2013, the first of a two-day televised interview was broadcast in which Armstrong admitted to Oprah Winfrey the truth of the charges against him for the first time and attempted to justify his actions.

Significant in his redemptive suffering, Armstrong's lifetime competition ban means that he could not compete in any sanctioned events, in any sport. Over the next few years, Armstrong came to realize the extent to which he could not compete in his new state of exile. In April 2013, he attempted to swim in a local United States Master's Swimming (USMS) meet in Austin Texas. He registered believing that because the meet had no professional outcomes, nor prize money, that his involvement was allowed. But when the World Anti-Doping Agency (WADA) heard of his registration, they contacted the International Swimming Federation (FINA) who asked the local sponsors of the meet to bar his involvement. Armstrong said "I was told all along that I was more than welcome to compete in masters meets by U.S.M.S. Then all of a sudden, I'm not welcome? I don't get it." (Macur 2013). He was also stopped a year and a half later from riding in his former teammates George Hincapie's Gran Fondo ride. While Armstrong was not involved in any competition, the fact that results from the event were submitted to the National Ranking System meant that Armstrong was not allowed to participate (Farrand 2014).

As Armstrong was clearly exiled from sport and competition, he also suffered an exile from those who had found meaning in his hero-athlete status. Along with his exit from LIVESTRONG, there was well documented backlash against him as a person and inspirational figure. Internet videos were 
posted of people cutting their yellow LIVESTRONG bracelets (Rapoport 2013), burning his books, and many attempted to return LIVESTRONG items to stores for refunds (Kelly 2013). Any review of comments posted to Armstrong's social media at the time, and since, reveal the fervent anger and pain his revelations caused.

Since his 'fall,' Armstrong has existed in relative exile, facing the fallout of his actions and living a life away from the sport and spotlight that made him a hero-athlete. The one thing that Armstrong was not allowed to do was return to professional sports. I contend this has been redemptive in that he was not allowed to return to the activities that placed him in exile in the first place. Here, we can apply Isaiah once again, as the Jewish exiles did not return to their former city, which had been razed by the Babylonians. Rather what Isaiah describes is the return to a 'new' Jerusalem, where the lessons learned from their exile restore them to God's favor and gives them hope for a better future.

\subsection{Beginnings of a New Hope}

By the end of Isaiah (chp. 56-66), details are provided about the redemptive hope described earlier in the book. We read about the promised reward of the faithful, the "righteous" servants and how they will be separated from those who continue to repeat the sins and errors of the previous generations, "the wicked" (Roberts 136). Those who see the new Jerusalem for what it is, another promised fulfilled by God, will live in hope. It is clear, however, that the new hope is not extended to all who returned from Babylon. Isaiah states that God will extend this newness and hope only to the faithful, not the whole nation (Dumbrell 1985, pp. 126-27). Here, the limits of redemption in Isiah where God redeems everyone, but not all will see or live the life of redemption, is apparent. Hanson (1975) explains how not all Jews will come to receive the benefits and redemption of their return from exile. Dumbrell states that God has divided the exiles into "'my people'" and "'those who forget my holy mountain'" (65:11). What is illustrated in the exiles' return from Babylon is that in this 'new' Jerusalem and relationship with God, some receive full redemption while others, though returned from exile, do not. The servants will profess their sins and lament the evil they see, asking for God's forgiveness, while the wicked returned from exile and believe themselves to be redeemed, returning to 'old' ways.

As I have said earlier, Armstrong is different from other fallen athletes in that he was never allowed to compete again and regain his former hero-athlete image through competition. I contend that this renders his portrayal to that of a servant. Other forgiven athletes are 'redeemed' because they go back to sports' elevated status and are reflective of the wicked described in Isaiah. They are wicked because they return to their previous elevated status as athlete, and not necessarily because they re-engage in improper behaviors. They return to a system that is flawed, whereas Armstrong was never allowed to re-enter the flawed system. This revelation has slowly come to be observable as I have documented Armstrong's reactions and interactions in popular culture more recently.

Many of Armstrong's first reactions were less than humble or conciliatory. During the early part of his exile, as noted above, he attempted to participate in events he was barred from, claiming he was being singled out in a sport riddled with doping scandals. "Despite moving away from professional cycling Armstrong remains convinced that he was made some kind of scapegoat and has paid for the sins of his generation and even the generation that proceeded his career ... " (N.A. 2014). Armstrong consistently presented an air of righteous contempt for the way he was banned and exiled. In interviews, he expresses bitterness, anger, and defiance in the face of his 'fall.' When offered opportunities to help investigators, he was less than willing at first. He called authority figures at USADA names, labeling them in unflattering ways. Many said of his initial apology with Oprah that he never cried or showed emotion, therefore he could not be sorry for what he did, only that he was caught (Karlinsky and Castellano 2013).

It is difficult to tell what is going on in someone's heart, or what their true feelings are, from an interview. I suspend my own judgement of Armstrong's early public presentations of himself through the media as he struggled with his persona non grata reality. But his defiance and the chip on his shoulder is well documented in articles and interviews. Sanderson and Hambrick (2016) write of 
Armstrong's attempts at apologizing, asking whether his was a case of an authentic apology. Did he really regret what he did, or were his attempts at apology attempts to repair his tarnished image? Did he really feel bad about the pain he caused, or just that he was finally caught? I contend we can never say for sure. However, analyzing the evolution of his apologies and the regret he displays, one can see how his regret today is different from the regret he espoused in the early years of his exile.

After two years of exile, opportunities for redemption of the contemporary sport culture ilk, especially related to cycling's governing body, started to appear. In late 2014, then president of the International Cycling Union (UCI) Brian Cookson stated "I think there is potential for redemption for him and anyone, really. I think it all depends on what (Armstrong) said to the commission and if he was prepared to talk about his or other people's involvement and whether he's genuinely contrite and deserving of redemption" (Windsor 2014). Armstrong stated that he wished to work with the Cycling Independent Reform Commission (CIRC), a commission formed to investigate cycling's doping past. In doing so, the commission had the authority to offer reduced sentences to those who fully cooperate and testify. Armstrong stated, "I've always said I will make myself fully available to an international commission tasked with helping our sport heal and move forward after multiple generations of rampant doping" (Benson 2014).

In 2016, after serving four years of his lifetime ban, and under very limited press release, Armstrong was granted an allowance in which "he can compete in a sanctioned event at a national or regional level in a sport other than cycling that does not qualify him ... to compete in a national championship or international event" (Schrotenboer 2016). Armstrong has also described his attempts at apology and seeking forgiveness and redemption by those he individually hurt. "I've apologised multiple times [to Betsy Andreu] ... What I've learned is you can't force someone to accept an apology ... I've traveled the world to make it right with these people ... Not only did I say [sorry] ... but I meant it. I don't know what else I need to do" (N.A. 2016). In 2018, Armstrong settled for \$5 million with the U.S. government for defrauding taxpayers and lying to the government. (Schrotenboer 2018).

I argue, however, that these examples of lifting certain aspects of a lifetime ban or paying the government, are not examples of the kind of redemption reflected in Isaiah. While Armstrong has made attempts to apologize on national television and to individual persons, his circumstances fall to the limitations detailed earlier, that an athlete can never speak to everyone and ask for forgiveness, to attain redemption. By the contemporary sport culture standards, Armstrong may have gotten his 'license to ride' back and settled with the federal government, but in a May 2019 interview (NBCSports.com), we can see a deeper redemption in the answers Armstrong provides, demonstrating that he has truly suffered and has come to a more humble and profound understanding of himself and his predicament, reflecting Isaiah's description of the humble servant after exile.

\subsection{Glimpses of Redemption}

In May of 2019, an interview was published in which Armstrong answered questions of where he was now (Brennan 2019). Many familiar questions were posed, but the interesting thing about this interview was the depth to which the usually stoic Armstrong went with his answers, and his emotional vulnerability. Three times in the interview (a familiar count for Biblical fans), Armstrong answered the question if he could do it all over, what would he change. His answer was "nothing"; he would not change a thing (Gaydos 2019; Busbee 2019). In previous interviews, he had stated that people did not like this answer. But in the 2019 interview, he said he would do it all over again, because it led him to sitting in that chair, having experienced all the pain and suffering of his exile. He was unburdened, he was free, he had learned his lessons from his mistakes and he no longer looked to others to justify his actions. He stated that if he had not done what he did, experienced it all, he would not have come to be a better person (Busbee 2019). Throughout the interview, we see a man who has been redeemed. Not by the millions of fans, the UCI, nor the U.S. government. Lance Armstrong was redeemed by a new understanding of the pain and suffering he experienced and has moved into a place where he is experiencing the newness of a life of hope. Lance Armstrong reflects the version 
of redeemed exiles in Isaiah that are servants of God, and not those granted a return from exile but return to a sport culture that inherently encourages and develops 'wicked ways', even if they never repeat bad behaviors. By not returning to sport, Lance Armstrong reflects Isaiah's image of a redeemed servant through the pain, suffering and exile he experienced.

\section{Three Themes of Redemption}

There are three points with which I wish to conclude this comparison; they are related to the role of contemporary sport culture, redemption, and Biblical themes from the book of Isaiah found in the popular media representation of Lance Armstrong. These themes echo Brueggemann's (1984) analysis of Isaiah, which I contend help sport scholars understand the global challenge of forgiving sport celebrities when they err in and out of sport performances.

The first point I wish to make here, as alluded to earlier in the paper, is that sport organizations, sport media, and the general public must rethink what it means to redeem athletes. As I have stated throughout, the common practice today is for athletes who make mistakes, such as Armstrong, to serve a certain punishment after which they can play again. When an athlete is found to have acted or behaved in a manner contrary to the law, social norms, or moral codes, we often think of them as redeemed when they return to and succeed in their sport (Scholes and Sassower 2014). However, if we are to follow the path toward redemption laid out in Isaiah, what we must consider is if returning athletes to sporting environments, that perhaps encouraged their behavior in the first place, is truly redemptive. For Armstrong, the lifetime ban 'saved' him from his return to professional sport and thus freed him from the lie he was living. It also forced him to look elsewhere for meaning in his life, in his case therapy and self-evaluation (Brennan 2019). But the fame, accolades, and elite status returned to Tiger Woods following his 2019 Master's victory, or Michael Vick, could very well lead to similar ideations of elevated status that caused transgressions in the first place. I am not claiming that any time an athlete gets in trouble, they should be banned for life. I am asking the reader to admit that we celebrate 'fallen' athletes when they return, because we watched them 'fall' and then had the gumption to return and perform. To me, this seems like Isaiah's descriptions of the wicked who return from exile, only to engage in the same behaviors and under similar circumstances as they did before. They misbehave, are punished, and then return to play again. Whether or not they re-engage in similar unethical behaviors, professional athletes exist in a sport culture that nevertheless provides opportunities for, even perhaps encourages, unethical behavior. We must, as Brueggemann contends, follow the calls of Isaiah for social criticism of the way 'fallen' sport stars return to play and examine the contemporary culture of sport before we make any strong claims that athletes who return to play have been redeemed. Armstrong was not allowed to do that, and I contend he is better as a person because of it.

Secondly, consumers and scholars of sport should acknowledge the pain and suffering as essentially necessary for redemption. When an athlete pays a fine, or serves a suspension, we often have not inflicted adequate pain and suffering to achieve the desired effect of true redemption. When an athlete returns to their sport following an infraction, and regardless of the degree of their punishment, an opportunity to return to their 'old ways' is ever-present. Lance Armstrong experienced what many deem to be adequate pain, as his punishment reflects an ultimate end that allowed his redemption away from the context of sport. In his 2019 interview with Mike Tirico (Brennan 2019), he states that had he not doped, lied, and been such a hurtful person he would not have been so punished, and thus he would not have learned the lessons he has through the process. Because he was not allowed to compete, he never could be redeemed through sport. This was true pain as it effected his career, finances, social status, and individual sense of self. His full redemption would not have been possible if he had been allowed back to sport. Without the painful suffering, he would not have learned the deeper lessons and become a better person. In relation to Isaiah's humble servant, we can also understand that through his story, Armstrong is an example of painful suffering leading to redemption. Not redemption in sport, but redemption as a person, a human who experienced deep pain and learned a new truth 
about what he did and how he has been changed by that truth. As we learn in Isaiah, God uses pain and suffering, through the exile of His people, to show them a new and better way to live. In Isaiah, we read "commentary explaining how this return has been achieved, namely though the ministry of the servant who has suffered so extremely, 52:13-53:12." (Dumbrell 1985, p. 126). Armstrong needed to suffer so that a new truth could be revealed to him and others. Helping an investigation, being contrite, paying a fine, or sitting out a few games are how other athletes have been 'redeemed' by a deeply flawed contemporary sport culture. Athletes only see the path to return to their elevated status at the sport table, and the culture of contemporary sport reinforces this. Again, I contend Armstrong's lifetime ban saved his chances for holistic redemption of a different, soulful, and more meaningful kind. It allowed him to suffer so greatly that he was redeemed as a person, not just as a hero-athlete.

This critique of contemporary sport culture's false redemption and the necessary painful suffering of individual athletes to achieve Biblical redemption, point to a third redemption theme for Armstrong; there is hope for those in despair. Armstrong is an example of a 'fallen' athlete, who was denied any chances of redeeming himself through sport and has shown himself to be better for it. He symbolizes the hope that there are new ways of imagining redemption (Brueggemann 1984, p. 102) for athletes after a great 'fall.' Paying a fine and returning to the pitch is all well and good. But the full extent of Armstrong's suffering demonstrates that there can be even greater redemption for an athlete who can never return to their sport. Unfortunately, this hope is lost in contemporary sport culture, where athletes, the media, and fans see a ban, punishment, or fine as another obstacle to overcome, and never truly learn lessons found in the deep pain and suffering that leads to the kind of redemption found in Isaiah's humble servant. These humble servants suffered through the exile and came back to live a life of newness and hope. This is observable in the case of Armstrong, who has articulated this change and accepted that he would not change a thing, even though it was hard and painful. It is precisely because it was hard and painful that he has emerged new and filled with hope. His example gives hope that there is redemption beyond the field of sport for fallen athletes, and it is a hope that sport scholars and those in sport media should celebrate and look for when the next athlete or sportsperson returns to their previous sport life and is said to have found redemption (Wilson 2019).

Armstrong could not be forgiven nor redeemed in the first years of his admittance; he had not begun his exile and painful journey of punishment. But after the lasting pain, from sources he could not anticipate, we see his redemption as a person and as described in Isaiah. For as Brueggemann (1984) states, "the hope is both permitted and required only by the suffering faced and claimed by the exiles ... And where there is no guilt and grief, there will not be comfort spoken ... The hopeful poetry of Second Isaiah is scarred and is spoken by one who knows" (p. 96).

\section{Conclusions}

Lance Armstrong represents a complicated figure in the mythos of contemporary sport. His story is filled with evidence of a biblical redemption found in the book of Isaiah. The deep pain and hurt experienced in both cases also lead one to appreciate and conceive of the truth that emerges. Stemming from the discussions presented here, future scholarship should focus on critiquing the nature of professional sports, and particularly the sport of cycling, that encourages athletes towards unethical means of achieving desired performances. It is also helpful to remember at the end here, that God did not return His chosen people from exile just for themselves, but for a "deeper soteriological meaning, and with world-wide implications" (Anderson 1962, p. 194). This truth is that only through deep pain and suffering, after a transgression has taken place (whatever the context), can one come to be redeemed as a person. Armstrong's May 2019 interview reveals his acceptance that "suffering need not be shunned but can be received as a way to live that opens the future" (Brueggemann 1984, p. 97).

Through Armstrong's suffering and exile, we observe his evolution for explaining his actions; from defiant, to angry, to contrite, to smug, to nervous, to calm and genuine. He is right when he acknowledges that people do not like it when he says he would do it all over again. But given the context of Isaiah, his evolution reveals the truth that without pain and suffering through an exile, 
he could not learn, grow, and find redemption. Contemporary sport culture tells us that redemption for athletes culminates when a 'fallen' athletes returns to play and is assured when they win. But deeper, more meaningful, redemption of the person requires suffering the kind Armstrong experienced. He had to fall and suffer so that he could share his story and experience to show us all how to hope for a better future for sports, athletes, and life. Brueggemann (1984) suggests "it is the very act of exile, lamentation, guilt and grief which now is overcome by the act of embrace" (p. 99). Only in pain and exile can one imagine a new reality and hope for a brighter future. We should all see Lance Armstrong as a person worthy of redemption and as a reminder of the good that can always be found from the bad.

Funding: This research received no external funding.

Conflicts of Interest: The author declares no conflict of interest.

\section{References}

Albanese, Catherine L. 1981. America: Religions and Religion. Belmont: Wadsworth Publishing Company.

Allison, Scott T., and George R. Goethals. 2011. Heroes: What They Do and Why We Need Them. New York: Oxford University Press.

Anderson, Bernard W. 1962. Exodus Typology in Second Isaiah. In Israel's Prophetic Heritage: Essays in Honor of James Muilenburg. Edited by Bernard W. Anderson and Walter Harrelson. Manhattan: Harper \& Brothers, pp. 177-95.

Benson, Daniel. 2014. Lance Armstrong Set for Second Meeting with CIRC. Cycling News. October 28. Available online: http://www.cyclingnews.com/news/lance-armstrong-set-for-second-meeting-with-circ/ (accessed on 28 October 2014).

Brennan, Daniel. 2019. WATCH: Lance Armstrong's full Interview with Mike Tirico. NBCSports.com. May 29. Available online: https://sports.nbcsports.com/2019/05/29/watch-lance-armstrong-full-interview-with-miketirico-video-tour-de-france-cycling/ (accessed on 7 June 2019).

Brueggemann, Walter. 1984. Unity and Dynamic in the Isaiah Tradition. Journal for the Study of the Old Testament 29: 89-107. [CrossRef]

Busbee, Jay. 2019. Lance Armstrong in NBCSN interview: 'I wouldn't change the way I acted'. Yahoo! Sports. May 30. Available online: https://sports.yahoo.com/lance-armstrong-in-nbcsn-interview-i-wouldnt-change-theway-i-acted-150314078.htm (accessed on 7 June 2019).

Clements, Ronald E. 1982. The Unity of the Book of Isaiah. Interpretation: A Journal of Bible and Theology 36: 117-29. [CrossRef]

Dumbrell, William. 1985. The Purpose of the Book of Isaiah. Tyndale Bulletin 36: 111-28.

Farrand, Stephen. 2014. USA Cycling Stops Armstrong Riding the Gran Fondo Hincapie. Cyclingnews. October 23. Available online: http://www.cyclingnews.com/news/usa-cycling-stops-armstrong-riding-the-gran-fondohincapie/ (accessed on 23 April 2014).

Gaydos, Ryan. 2019. Lance Armstrong Says He 'Wouldn't Change a Thing' about Doping Scandal that Cost Him 7 Tour de France Titles. Fox News. May 24. Available online: https://www.foxnews.com/sports/lancearmstrong-no-regrets-doping-tour-de-france (accessed on 7 June 2019).

Guttmann, Allen. 2004. Sport: The First Five Millennia. Boston: University of Massachusetts Press.

Hanson, Paul. 1975. The Dawn of Apocalyptic. Philadelphia: Fortress Press.

Harner, Ph. B. 1967. Creation Faith in Deutero-Isaiah. Vetus Testamentum 17: 298-306. [CrossRef]

Hoffman, Shirl J. 1992. Sport and Religion. Champaign: Human Kinetics.

Karlinsky, Neal, and Anthony Castellano. 2013. Lance Armstrong May Have Lied to Winfrey: Investigators. ABC News. January 18. Available online: https://abcnews.go.com/US/lance-armstrong-lied-oprah-cover-crimesinvestigators/story? $\mathrm{id}=18245484$ (accessed on 20 January 2013).

Kelly, Jon. 2013. Should Buyers of Lance Armstrong's Books Get a Refund? BBC. February 4. Available online: https://www.bbc.com/news/magazine-21250032 (accessed on 27 March 2013).

Kennedy, Merrit. 2019. Tiger Woods Rises Again—And Sponsors Are Celebrating His Resilience. NPR. April 15. Available online: https://www.npr.org/2019/04/15/713443562/tiger-woods-rises-again-and-sponsors-arecelebrating-his-resilience (accessed on 20 April 2019). 
King, Samantha. 2006. Pink Ribbons, Inc.. Minneapolis: University of Minnesota Press.

Levy, Dan. 2012. Lance Armstrong Let Pride and Hubris, Not Doping, Ruin His Legacy. Bleacher Report. August 24. Available online: https://bleacherreport.com/articles/1309680-lance-armstrong-let-pride-and-hubris-notdoping-ruin-his-legacy (accessed on 20 September 2012).

Linder, Robert D. 1975. Civil Religion in Historical Perspective. Journal of Church and State 17: 399-421. [CrossRef] Macur, Juliet. 2013. Disappointed Armstrong Stopped from Competing in Swimming. New York Times. April 4. Available online: https://www.nytimes.com/2013/04/05/sports/cycling/armstrong-plans-to-enter-swimmingcompetition.html (accessed on 20 April 2013).

Mathisen, James A. 1992. From Civil Religion to Folk Religion: The Case of American Sport. In Sport and Religion. Edited by Shirl Hoffman. Champaign: Human Kinetics.

Meyer, Andrew R. 2012. Muscular Christian themes in contemporary American sport: A case study. The Journal of the Christian Society for Kinesiology, Leisure, and Sport Studies 2: 15-32.

Milbank, John, Catherine Pickstock, and Graham Ward, eds. 1999. Radical Orthodoxy: A New Theology. London: Routledge.

Millar, Robert. 2013. The Long Road to Redemption: Lance Armstrong Realizes It's OK to be Human. CNN. January 18. Available online: https://www.cnn.com/2013/01/18/sport/robert-millar-armstrong-oprah-cycling/ index.html (accessed on 15 June 2019).

N.A. 2014. Armstrong Says Cycling is Still in a Mess after His Doping Confession. Cycling News. November 5. Available online: http://www.cyclingnews.com/news/armstrong-says-cycling-is-still-in-a-mess-after-hisdoping-confession/ (accessed on 20 December 2014).

N.A. 2016. I Was a Complete Dickhead. Newstalk. October 7. Available online: https://www.newstalk.com/sport/iwas-a-complete-dickhead-lance-armstrong-off-the-ball-71405 (accessed on 20 October 2016).

Nelson, Dean. 2009. 'Holy' Moments Surround Us: You Don't Have to be Religious to Know That There's Something Bigger Out There, Often in Plain Sight. USA Today. October 26. Available online: http: //deannelson.net/docs/usa_today.pdf (accessed on 30 June 2019).

Novak, Michael. 1992. The Natural Religion. In Sport and Religion. Edited by Shirl Hoffman. Champaign: Human Kinetics.

Oriard, Michael. 1982. Dreaming of Heroes. Chicago: Nelson-Hall.

Pelletier, Justin. 2019. Masters Champion Tiger Woods, Love Him or Hate Him, Good for the Game. The Boston Globe. April 14. Available online: https://www.bostonherald.com/2019/04/14/masters-champion-tiger-woodslove-him-or-hate-him-good-for-the-game/ (accessed on 20 April 2019).

Pucin, Diane. 2009. The Chase is on Again. Los Angeles Times. January 19. Available online: https://www.latimes. com/archives/la-xpm-2009-jan-19-sp-tour-lance-armstrong19-story.html (accessed on 10 February 2009).

Rapoport, Abby. 2013. Austin Loses its Hometown Hero. The American Prospect. January 18. Available online: https://prospect.org/article/austin-loses-its-hometown-hero (accessed on 16 August 2019).

Rishe, Patrick. 2012. Armstrong Will Lose $\$ 150$ Million in Future Earnings after Nike and Other Sponsors Dump Him. Forbes. October 18. Available online: https://www.forbes.com/sites/prishe/2012/10/18/nike-provesdeadlier-than-cancer-as-armstrong-will-lose-150-million-in-future-earnings/\#5f22cf766298 (accessed on 20 October 2012).

Roberts, Jimmy Jack McBee. 1982. Isaiah in Old Testament Theology. Interpretation: A Journal of Bible and Theology 36: 130-43. [CrossRef]

Rotunno, Tom. 2012. Armstrong Loses Eight Sponsors in a Day. CNBC. October 18. Available online: https://www.cnbc.com/id/49462583 (accessed on 20 October 2012).

Sanderson, Jimmy, and Marion E. Hambrick. 2016. Riding along with Lance Armstrong: Exploring Antapologia in Response to Athlete Adversity. Journal of Sports Media 11: 1-24. [CrossRef]

Sansone, David. 1988. Greek Athletics and the Genesis of Sport. Berkeley: University of California Press.

Scholes, Jeffrey, and Raphael Sassower. 2014. Religion and Sport in American Culture. London: Routledge.

Schrotenboer, Brent. 2016. Lance Armstrong's ban is partially lifted. USA TODAY Sports. September 7. Available online: https://www.usatoday.com/story/sports/cycling/2016/09/07/lance-armstrong-cycling-ban-partiallylifted/89981404/ (accessed on 17 September 2016).

Schrotenboer, Brent. 2018. Lance Armstrong Agrees to \$5 million Settlement of Government Lawsuit. CNBC. April 20. Available online: https:/www.cnbc.com/2018/04/20/lance-armstrong-agrees-to-5-million-settlement-ofgovernment-lawsuit.html (accessed on 20 April 2018). 
Sydnor, Synthia. 2003. The Radical Orthodoxy Project and Sport History. In Transitions in Sport History: Continuity and Change in Sport History. Edited by Wolfgang Buss and Arnd Kruger. Hanover: R. Kunz; Schriftenreihe des Niedersächsischen Instituts für Sportgeschichte, pp. 24-39.

USADA. 2012. Lance Armstrong Receives Lifetime Ban and Disqualification of Competitive Results for Doping Violations Stemming from His Involvement in the United States Postal Service Pro-Cycling Team Doping Conspiracy. U.S. Anti-Doping Agency. August 24. Available online: https://www.usada.org/ lance-armstrong-receives-lifetime-ban-and-disqualification-of-competitive-results-for-doping-violationsstemming-from-his-involvement-in-the-united-states-postal-service-pro-cycling-team-doping-conspi/ (accessed on 24 August 2012).

Williams, Armstrong. 2009. Absurdity of Athlete Worship. The Washington Times. December 4. Available online: https://www.washingtontimes.com/news/2009/dec/14/the-absurdity-of-athlete-worship/ (accessed on 20 December 2009).

Wilson, Dave. 2019. How a small Texas town has reacted to the hiring of Art Briles. ESPN.com. July 11. Available online: https://www.espn.com/college-football/story/_/id/26943300/how-small-texas-town-reacted-hiringart-briles (accessed on 14 July 2019).

Windsor, Richard. 2014. 'There is potential for redemption for Lance Armstrong' says Brian Cookson. Cycling Weekly. October 28. Available online: https:/www.cyclingweekly.com/news/latest-news/potential-redemption-lancearmstrong-says-brian-cookson-141604 (accessed on 1 November 2014).

(C) 2019 by the author. Licensee MDPI, Basel, Switzerland. This article is an open access article distributed under the terms and conditions of the Creative Commons Attribution (CC BY) license (http://creativecommons.org/licenses/by/4.0/). 